\title{
EFFECTIVENESS OF VARIOUS POTASSIUM SOURCES ON VEGETATIVE GROWTH, FLOWERING, ESSENTIAL OIL PRODUCTIVITY AND SOME CHEMICAL CONSTITUENTS OF YARROW (ACHILLEA MILLEFOLIUM L.) PLANT
}

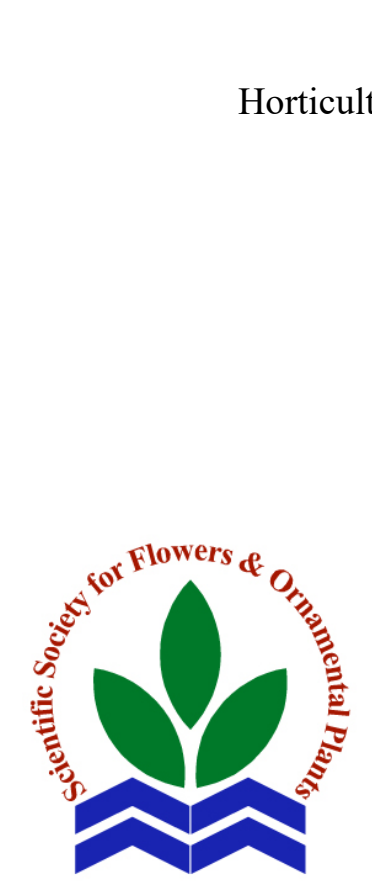

Scientific J. Flowers \& Ornamental Plants, 8(1):101-121 (2021).

Received:

$13 / 1 / 2021$

Accepted:

$10 / 2 / 2021$

Corresponding author: Y.A.A. Ghatas yaser.ghatas@fagr.bu.edu.eg

\author{
Y.F.Y. Mohamed and Y.A.A. Ghatas
}

ABSTRACT: Achillea millefolium is a major medicinal and aromatic herb and has antioxidant, antimicrobial, antispasmodic and antitumor effects in its essential oil. This research was conducted at Floriculture Farm and in the Laboratories of Horticulture Departments, Faculty of Agriculture at Moshtohor, Benha Univ., during 2018/2019 and $2019 / 2020$ seasons to study the effect of foliar spraying at $2000 \mathrm{mg} / 1$ with various potassium sources i.e., potassium chloride, potassium citrate, potassium humate, potassium nitrate, potassium silicate, potassium sulphate, monopotassium phosphate and di-potassium hydrogen phosphate on vegetative growth, flowering, essential oil productivity and some chemical constituents of yarrow (Achillea millefolium L.) plants. Results showed that various potassium sources scored highly significant effects on vegetative growth and flowering of A. millefolium L. plant, particularly potassium nitrate followed potassium humate. Moreover, the richest leaf $\mathrm{N} \%$ was resulted by potassium nitrate, whereas, spraying A. millefolium L. plants with monopotassium phosphate treatment induced the highest values of the percentage of $\mathrm{P}(\%)$ and total chlorophylls content (\%) as well as the maximum K (\%), while total carbohydrate content was given by potassium sulphate. In addition, spraying yarrow plant with potassium citrate treatment induced the maximum values of essential oil parameters. Furthermore, the constituents of volatile oil of $A$. millefolium L. showed 13 components have been recognized. The major components were $\alpha$-bisabolol oxide B, limonene, carvacrol and chamazulene. Consequently, spraying A. millefolium L. plants with potassium nitrate or potassium humate is recommended, to boost growth, flowering and some chemical constituents, whereas potassium citrate and potassium silicate treatment induced the richest values of essential oils production.

Key words: Achillea millefolium, potassium sources, growth, flowering, chemical composition and essential oil productivity and GLC.

\section{INTRODUCTION}

Achillea millefolium $\mathrm{L}$. is an ancient herbaceous medicinal plant belonging to the Asteraceae family, commonly known as Yarrow, thousand-leaf, pepper and thousandseal. Van Der Kooi et al. (2015). Achillea millefolium is $0.2-1 \mathrm{~m}$ in height and has a spreading rhizomatous growth shape, growing one to multiple stems. Leaves are spread uniformly around the stem, with the highest being the leaves in the center and bottom of the stem. The leaves have various types of hairiness (pubescence). The leaves 
are 5-20 $\mathrm{cm}$ long, almost feathery, bipinnate or tripinnate, and spirally arranged on the stems. Cauline, and more or less clasping, are the stems. There are 4 to 9 phyllaries in the inflorescence and ray and disk flowers, which are white to pink. The flowers are normally ovate to circular with 3 to 8 rays. Disk flowers differ between 15 and 40. A flat-toped capitulum cluster produces the inflorescence and many insects frequent the inflorescences with a generalized pollination scheme. Van Der Kooi et al. (2015). Yarrow is widely used due to its many pharmacological properties, such as antiinflammatory drugs, in folk medicine (Goldberg et al., 1969), antispasmodic (Falk et al., 1975), antiseptic (Candan et al., 2003), diaphoretic, anti-swelling, and antihypertensive (Sweetman et al., 2002), diuretic and antidiarrheal (Honda et al., 1996) and emmenagogue (Schulz et al., 2001). Nowadays, common yarrow is used in healing ointments applied to wounds (Sampson et al., 1997) and in modern medicine for reducing ulcer size (Nilforoushzadeh et al., 2008). It also has antitumor (Tozyo et al., 1994), antioxidant ingredients (Yaseen et al., 2017), antimicrobial-based (Candan et al., 2003), antifungal officers (Aydin and Sevindik, 2018), anti-mutagenic (Düsman et al., 2013), liver protective (Lin et al., 2002), muscle relaxant (Koushyar et al., 2013), gastric antisecretory and gastroprotective activities (Baggio et al., 2002). The yarrow flower contains of $0.2-0.5 \%$ essential oil, while the leaves and stem parts contain only $0.02-$ $0.07 \%$ (Hornok et al., 1974). Achillea millefolium L. essential oil contains mostly of mono- and sesquiterpenoids pinenes, sabinene, phellandrene, eucalyptol (1,8cineol), terpinen-4-ol and alpha-terpineol were the most important compounds in the first class, while $\beta$-caryophyllene, bornyl acetate, eudesmol, camazulene and alphabisabololol were the most important compounds in the second class. (Tuberoso and Kowalczyk, 2009; Rahimmalek et al., 2009; Bocevska and Sovová, 2007; Chalchat et al., 1999).
Potassium (K) is an important nutrient in plants this plays too significant function in plant growth and production. Its function in photosynthesis is all right known, growing the operation of enzymes, enhancing protein, carbohydrate and fat synthesis, translocating photosynthetics, enabling their capacity to withstand pests and diseases. $\mathrm{K}$ is often known as an important osmotically active cation in plant cells (Mehdi et al., 2007). Potassium is an essential nutrient for meristematic plant growth and physiological functions, including plant water and gas exchange control, protein synthesis, activation of enzymes, photosynthesis, and translocation of carbohydrates in plants. Potassium has a beneficial influence on the synthesis of nucleic acids, fats, vitamins and growth compounds. (Bisson et al., 1994; Bednarz and Oosterhuis, 1999). In addition, $\mathrm{K}$ increases water absorption and root permeability and, in addition to its function in increasing water usage quality, serves as a guard cell controller (Zekri and Obreza, 2009). Potassium has favorable effects on metabolism of nucleic acids, proteins, vitamins and growth substances (Bisson et al., 1994; Bednarz and Oosterhuis, 1999). Furthermore, $\mathrm{K}$ foliar applications can boost yield and tuber quality, especially in heavy clay or in sandy soils where $\mathrm{K}$ is not readily accessible to plants. (Marchand and Bourrie, 1999). Similar outlets for $K$ in this study such as potassium chloride, potassium citrate, potassium humate, potassium nitrate, potassium silicate, potassium sulphate, monopotassium phosphate and di-potassium hydrogen phosphate are used for plants nutrition (Magen 2004). Jabeen and Ahmad (2011) the beneficial effects of the application of $\mathrm{KNO}_{3}$ on growth, concentration of nutrients, activity of nitrate reductase and soluble proteins of sunflower and safflower plants were seen regardless of their growth under non-saline or saline conditions. Said-Al Ahl et al. (2009) declared that, in conjunction with nitrogen fertilizer levels $\left(0,0.6\right.$ and $1.2 \mathrm{~g} \mathrm{~N}^{-1}$ pot $^{-1}$ as ammonium sulphate), potassium-humate as foliar spraying at $1 \%$ improved the 
vegetative growth and essential oil of oregano plants. Abd El-Razik et al. (2015) illustrated that, combining the irrigation cycles with the application of potassium silicate, it was evident that the treatments had a marked impact on the quality of essential oil (\%) during all cuts of the chervil plant in both seasons. Ghatas and Mohamed (2020) mentioned that, the best for enhancing growth, seed production, fixed oil productivity, chemical constituents and fixed oil components of Oenothera biennis L. plant were monopotassium phosphate with EM or phosphorein. Farahani et al. (2020) declared that, the foliar application of $\mathrm{Si}$ at a concentration of $0.2 \%$ in spring and summer of rose plant, particularly under conditions of water stress, is useful for raising the content of essential oils and the concentration of geraniol, citronellol, eugenol and methyl eugenol, which are the key compounds useful for oil therapeutic, cosmetic and wellness applications. Therefore, the current research was intended to investigate the influence of different sources of potassium on vegetative growth, flowering, productivity of volatile oils and some chemical elements of yarrow (Achillea millefolium L.) plants.

\section{MATERIALS AND METHODS}

\section{Plant material:}

This research was conducted at the Experimental Farm and at the Department of
Horticulture Laboratories, Faculty of Agriculture, Moshtohor, Benha Univ. $2018 / 2019$ and 2019/2020 seasons to study the effect foliar spraying with various potassium sources i.e., potassium chloride, potassium citrate, potassium humate, potassium nitrate, potassium silicate, potassium sulphate, monopotassium phosphate and di-potassium hydrogen phosphate on vegetative growth, flowering, essential oil productivity and some chemical elements of yarrow (Achillea millefolium L.) plants.

Yarrow seeds have been sourced from Floriculture Farm, Department of Horticulture, Faculty of Agriculture, Benha Univ. Seeds of yarrow were sown in clay loam soils on $20^{\text {th }}$ October in both seasons in plots $(1.5 \times 1 \mathrm{~m})$ containing two rows $(75 \mathrm{~cm}$ in between) every row has two hills $(50 \mathrm{~cm}$ apart) and six weeks later, the plants were thinned, leaving only two seedlings/hill.

Physical and chemical analysis of the experimental soil were determined according to Jackson (1973) and Black et al. (1982), respectively. The obtained results of soil analysis are presented in Table (1).

\section{Experimental layout:}

A complete randomized block design with one element with three replicates was the architecture of the experiment. Every replication containing 5 plots, included 20

Table 1. The experimental soil mechanical and chemical analysis.

\begin{tabular}{|c|c|c|c|c|c|}
\hline \multicolumn{3}{|c|}{ Mechanical properties } & \multicolumn{3}{|c|}{ Chemical analysis } \\
\hline \multirow{2}{*}{ Parameters } & \multicolumn{2}{|c|}{ Values } & \multirow{2}{*}{ Parameters } & \multicolumn{2}{|c|}{ Values } \\
\hline & $2018 / 2019$ & $2019 / 2020$ & & 2018/2019 & $2019 / 2020$ \\
\hline Coarse sand (\%) & $6 . .88$ & 5.44 & Organic matter (\%) & 1.74 & 1.77 \\
\hline Fine sand $(\%)$ & 14.44 & 12.22 & $\mathrm{CaCO}_{3}(\%)$ & 0.72 & 0.79 \\
\hline Silt (\%) & 23.01 & 25.42 & $\begin{array}{l}\text { Available nitrogen } \\
\left(\mathrm{mg} \mathrm{kg}^{-1}\right)\end{array}$ & 0.68 & 0.71 \\
\hline Clay (\%) & 55.67 & 56.92 & $\begin{array}{l}\text { Available phosphorus } \\
\qquad\left(\mathrm{mg} \mathrm{kg}^{1}\right)\end{array}$ & 0.49 & 0.56 \\
\hline \multirow[t]{3}{*}{ Textural class } & Clay loam & Clay loam & $\begin{array}{l}\text { Available potassium } \\
\quad\left(\mathrm{mg} \mathrm{kg}^{-1}\right)\end{array}$ & 234 & 241 \\
\hline & & & pH & 7.71 & 7.66 \\
\hline & & & $E C(d S / m)$ & 0.74 & 0.81 \\
\hline
\end{tabular}


plants, i.e. 60 plants in each treatment, a consideration including nine separate treatments for potassium sources.

\section{Foliar spray of various potassium sources treatments:}

All yarrow plants were given potassium sources at the same concentration as foliar spray $(2000 \mathrm{mg} / \mathrm{l} \mathrm{K} 2 \mathrm{O})$. Multiple sources of potassium were sprayed as a foliar spray in five occasions. The $1^{\text {st }}$ application was conducted one month after transplantation. The $2^{\text {nd }}$ and $3^{\text {rd }}$ were applied two weeks after the first and the second, respectively. While the $4^{\text {th }}$ was applied after the first cutting the herbs and finally the $5^{\text {th }}$ was applied two weeks after the fourth. Spraying was performed up to the point of runoff. In all checked solutions, including the control, a surfactant (Tween-20) was applied at a concentration of 0.01 percent.

\section{The potassium sources were calculated as follows:}

1. The control treatment (spray with tap water) at $0 \mathrm{mg} / \mathrm{l}$ water.

2. Potassium chloride $\mathrm{KCl}\left(63.2 \% \mathrm{~K}_{2} \mathrm{O}\right), 3.2$ $\mathrm{g} / 1$ water as foliar spray.

3. Potassium citrate $\mathrm{K}_{3} \mathrm{C}_{6} \mathrm{H}_{5} \mathrm{O}_{7}\left(48 \% \mathrm{~K}_{2} \mathrm{O}\right)$, $4.2 \mathrm{~g} / 1$ water as foliar spray.

4. Potassium humate $\mathrm{KH}\left(11 \% \mathrm{~K}_{2} \mathrm{O}\right), 18.1$ $\mathrm{cm} / 1$ water as foliar spray.

5. Potassium nitrate $\mathrm{KNO}_{3}\left(46.6 \% \mathrm{~K}_{2} \mathrm{O}\right.$ and $13.8 \% \mathrm{~N}), 4.3 \mathrm{~g} / 1$ water as foliar spray.

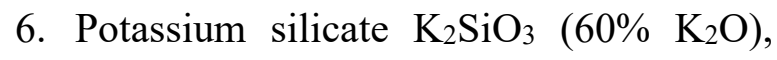
$3.3 \mathrm{~cm} / 1$ water as foliar spray.

7. Potassium sulphate $\mathrm{K}_{2} \mathrm{SO} 4\left(54 \% \mathrm{~K}_{2} \mathrm{O}\right.$ and $18.4 \% \mathrm{~S}), 3.7 \mathrm{~g} / 1$ water as foliar spray.

8. Monopotassium phosphate (potassium dihydrogen phosphate $\mathrm{KH}_{2} \mathrm{PO}_{4} \quad \mathrm{M} . \mathrm{W}$. 136.09) (34.6\% $\quad \mathrm{K}_{2} \mathrm{O}$ and $\left.52 \% \quad \mathrm{P}_{2} \mathrm{O}_{5}\right)$, $5.8 \mathrm{~g} / 1$ water as foliar spray.

9. Di-potassium hydrogen phosphate $\mathrm{K}_{2} \mathrm{HPO}_{4}\left(54 \% \mathrm{~K}_{2} \mathrm{O}\right.$ and $\left.40.8 \% \mathrm{P}_{2} \mathrm{O}_{5}\right), 3.7$ $\mathrm{g} / 1$ water as foliar spray.

All potassium sources were obtained from Abou Zaabal for Fertilizers and
Chemical Substances Co. except potassium humate was obtained from Technogene Crop., Dokki, Cairo, Egypt).

In addition, yarrow plants obtained chemical fertilizer at $200 \mathrm{~kg} /$ feddan N (using ammonium nitrate $(33 \% \mathrm{~N})$, calcium superphosphate $\left(\begin{array}{lll}15.5 \% & \left.\mathrm{P}_{2} \mathrm{O}_{5}\right)\end{array}\right)$ at $150 \mathrm{~kg}$ $\mathrm{P}_{2} \mathrm{O}_{5} /$ feddan and potassium sulfate $(48 \%$ $\mathrm{K}_{2} \mathrm{O}$ ) at $100 \mathrm{~kg}$ /feddan $\mathrm{K}_{2} \mathrm{O}$. A mixture of three fertilizers with a ratio of $1: 1: 1(\mathrm{~N}$ : $\mathrm{P}_{2} \mathrm{O}_{5}: \mathrm{K}_{2} \mathrm{O}$ ) Three additions were applied; the first fertilizer after 30 days of transplantation was added. The second was after 1 month from the first, while the third was applied after extracting the herbs. Calcium super phosphate ( 15 percent $\left.\mathrm{P}_{2} \mathrm{O}_{5}\right)$ was applied as a single dose during soil preparation during the two seasons of this study. Where appropriate, traditional agricultural practices (irrigation, fertilization, manual management of weeds, etc.) have been introduced.

\section{Harvesting:}

In each experimental season, plants were harvested at the time of the full-blooming period. For each crop, the plants were twice trimmed. The first cut was done on 15 February, and on 15 May the second cut was done between the 2019 and 2020 seasons.

\section{Data measurements and recorded:}

The vegetative and yield parameters were measured and recorded at harvesting time on 15 February and 15 May 2019 and 2020 seasons as follows: The vegetative parts were cut about $10 \mathrm{~cm}$ above the soil surface. Measurements of the following traits were collected:

\section{Characteristics of vegetative and flowering:}

- Plant height (cm).

- Number of branches/plant.

- Fresh weight of herb (g/plant).

- Dry weight of herb (g/plant).

- Number of inflorescences/plant.

- Fresh weight of flowers (g/plant).

- Dry weight of flowers (g/plant). 
- Dry weight of herbs and flowers (g/plant).

- Total dry yield (herb and flowers)/ season/feddan (ton).

\section{Chemical constituents :}

- Photosynthetic pigments: total chlorophylls in the fresh leaves were calorimetrically estimated according to the method defined by the A.O.A.C (1990) and fresh weight, measured as $\mathrm{mg} / 100 \mathrm{~g}$.

- Nitrogen, phosphorus, potassium and total carbohydrates: the dried yarrow leaves were calculated according to the methods mentioned by Horneck and Miller (1998), Hucker and Catroux (1980), Horneck and Hanson (1998) and Chaplin and Kennedy (1994), respectively.

\section{Essential oil parameters:}

- Essential oil percentage. the volatile oil percentage was calculated as $\mathrm{ml}$ of oil/100 grams of herbs and flowers using the following equation:

Essential oil percentage $=$ Oil volume in the graduated tube/dry weight of samples $\times 100$.

- Essential oil yield/plant (ml).

- Essential oil yield/plant of two cuts (ml).

- Essential oil yield/feddan (1).

Essential oil percentage of yarrow herbs and flowers was determined by hydro distillation according to the method of Guenther, (1961), the oil percentage was used to calculate essential oil yield/plant (ml), essential oil yield/ plant of two cuts (ml) and essential oil yield/feddan (l).

\section{GLC analysis of essential oil:}

GLC research was performed at the medicinal and aromatic plant laboratory for oil samples from the second season only after the first trial. Dokki Study of gas liquid chromatography was conducted by Guenther (1961) and British Pharm. (1963).

\section{Statistical analysis:}

The design of the experiment as simple experiments in a complete randomized block design at $p \leq 0.05$. The discrepancies between the mean values of different therapies. Duncan's multiple range test (Duncan, 1955) was compared. Using the MSTAT-C statistical program package as given by (Snedecor and Cochran, 1989).

\section{RESULTS AND DISCUSSION}

\section{Vegetative growth parameters:}

Tables (2 and 3) demonstrated that, foliar spraying with a various of potassium sources, i.e. potassium chloride, potassium citrate, potassium humate, potassium nitrate, potassium silicate, potassium sulphate, monopotassium phosphate and di-potassium hydrogen phosphate, showed highly significant results at $2000 \mathrm{mg} / \mathrm{l}$ of plant height, number of branches, and fresh and dry weight of Achillea millefolia herbs (g/plant) particularly potassium nitrate, with plant height exception in both cuts and in the 1 st and 2 nd seasons. The tallest yarrow plant was recorded by the treatment of potassium humate followed by potassium nitrate. Moreover, the treatment of potassium sulphate significantly enhanced the parameters mentioned above. Irrespective control, the minimum values of these parameters were achieved by potassium chloride in the two cuts and seasons.

The rise in yarrow plant vegetative growth which sprayed with potassium sources may be due to it the role of potassium in plant nutrition, i.e. the promotion of the function of enzymes and the improvement of assimilate translocation and protein synthesis. With regard to this relation, Sangakkara et al. (2000) the increase in yarrow plant growth has been due to the role of $\mathrm{K}$ in biochemical pathways in plants, increasing photosynthetic rates, $\mathrm{CO}_{2}$ assimilation and promoting carbon movements. Marschner (2012) reported that 
Table 2. Effect of foliar application of different potassium sources on plant height $(\mathrm{cm})$, number of branches/plant and fresh weight of herb (g/plant) of Achillea millefolium $\mathrm{L}$. plant during 2018/2019 and 2019/2020 seasons.

\begin{tabular}{|c|c|c|c|c|c|c|}
\hline \multirow{2}{*}{ Treatments } & \multicolumn{2}{|c|}{ Plant height (cm) } & \multicolumn{2}{|c|}{$\begin{array}{c}\text { Number of } \\
\text { branches/plant }\end{array}$} & \multicolumn{2}{|c|}{$\begin{array}{c}\text { Fresh weight of } \\
\text { herb (g/plant) }\end{array}$} \\
\hline & $1^{\text {st }}$ cut & $2^{\text {nd }}$ cut & $1^{\text {st }}$ cut & $2^{\text {nd }}$ cut & $1^{\text {st }}$ cut & $2^{\text {nd }}$ cut \\
\hline & \multicolumn{6}{|c|}{ First season $(2018 / 2019)$} \\
\hline Control (tap water) at $0 \mathrm{mg} / \mathrm{l}$ & $68.22 \mathrm{~h}$ & $64.31 \mathrm{f}$ & $30.33 \mathrm{~g}$ & $61.67 \mathrm{~g}$ & $367.6 \mathrm{i}$ & $391.3 \mathrm{i}$ \\
\hline Potassium chloride at $2000 \mathrm{mg} / \mathrm{l}$ & $71.44 \mathrm{~g}$ & $73.31 \mathrm{e}$ & $32.33 \mathrm{f}$ & $64.67 \mathrm{f}$ & $421.4 \mathrm{~h}$ & $480.3 \mathrm{~h}$ \\
\hline Potassium citrate at $2000 \mathrm{mg} / \mathrm{l}$ & 75.29 ef & $77.05 \mathrm{~d}$ & $36.67 \mathrm{e}$ & $69.33 \mathrm{e}$ & $568.0 \mathrm{~g}$ & $631.9 \mathrm{f}$ \\
\hline Potassium humate at $2000 \mathrm{mg} / \mathrm{l}$ & $91.46 \mathrm{a}$ & $89.50 \mathrm{a}$ & $46.67 \mathrm{~b}$ & $77.67 \mathrm{~b}$ & $630.2 \mathrm{~b}$ & $744.3 \mathrm{~b}$ \\
\hline Potassium nitrate at $2000 \mathrm{mg} / \mathrm{l}$ & $89.31 \mathrm{~b}$ & $85.65 \mathrm{~b}$ & $49.33 \mathrm{a}$ & $80.67 \mathrm{a}$ & $640.2 \mathrm{a}$ & $761.4 \mathrm{a}$ \\
\hline Potassium silicate at $2000 \mathrm{mg} / \mathrm{l}$ & $74.74 \mathrm{f}$ & $71.96 \mathrm{e}$ & $36.33 \mathrm{e}$ & $69.33 \mathrm{e}$ & $579.0 \mathrm{f}$ & $620.6 \mathrm{~g}$ \\
\hline Potassium sulphate at $2000 \mathrm{mg} / \mathrm{l}$ & $81.74 \mathrm{c}$ & $77.97 \mathrm{~cd}$ & $40.00 \mathrm{~d}$ & $70.33 \mathrm{e}$ & $619.4 \mathrm{~d}$ & $660.0 \mathrm{e}$ \\
\hline Monopotassium phosphate at $2000 \mathrm{mg} / \mathrm{l}$ & $79.56 \mathrm{~d}$ & $79.14 \mathrm{c}$ & $39.67 \mathrm{~d}$ & $73.33 \mathrm{~d}$ & $615.7 \mathrm{e}$ & $689.9 \mathrm{~d}$ \\
\hline \multirow[t]{2}{*}{ Di-potassium hydrogen phosphate at $2000 \mathrm{mg} / \mathrm{l}$} & $76.66 \mathrm{e}$ & $79.39 \mathrm{c}$ & $43.67 \mathrm{c}$ & $75.67 \mathrm{c}$ & $623.4 \mathrm{c}$ & $710.2 \mathrm{c}$ \\
\hline & \multicolumn{6}{|c|}{ Second season $(2019 / 2020)$} \\
\hline Control (tap water) at $0 \mathrm{mg} / \mathrm{l}$ & $69.33 \mathrm{~g}$ & $63.39 \mathrm{f}$ & $33.67 \mathrm{~h}$ & $63.67 \mathrm{~g}$ & $371.3 \mathrm{i}$ & $411.4 \mathrm{i}$ \\
\hline Potassium chloride at $2000 \mathrm{mg} / \mathrm{l}$ & $72.33 \mathrm{f}$ & $71.59 \mathrm{e}$ & $36.67 \mathrm{~g}$ & $67.33 \mathrm{f}$ & $461.3 \mathrm{~h}$ & $510.3 \mathrm{~h}$ \\
\hline Potassium citrate at $2000 \mathrm{mg} / \mathrm{l}$ & $75.97 \mathrm{e}$ & $73.54 \mathrm{e}$ & $39.00 \mathrm{f}$ & $69.67 \mathrm{e}$ & $609.9 \mathrm{f}$ & $660.3 \mathrm{f}$ \\
\hline Potassium humate at $2000 \mathrm{mg} / \mathrm{l}$ & $92.29 \mathrm{a}$ & $90.35 \mathrm{a}$ & $48.67 \mathrm{~b}$ & $79.33 \mathrm{~b}$ & $673.7 \mathrm{~b}$ & $761.7 \mathrm{~b}$ \\
\hline Potassium nitrate at $2000 \mathrm{mg} / \mathrm{l}$ & $89.38 \mathrm{~b}$ & $88.67 \mathrm{a}$ & $51.00 \mathrm{a}$ & $82.33 \mathrm{a}$ & $681.3 \mathrm{a}$ & $778.9 \mathrm{a}$ \\
\hline Potassium silicate at $2000 \mathrm{mg} / \mathrm{l}$ & $75.33 \mathrm{e}$ & $73.56 \mathrm{e}$ & 39.33 ef & $70.00 \mathrm{e}$ & $604.2 \mathrm{~g}$ & $650.9 \mathrm{~g}$ \\
\hline Potassium sulphate at $2000 \mathrm{mg} / \mathrm{l}$ & $85.45 \mathrm{c}$ & $83.10 \mathrm{~b}$ & $40.33 \mathrm{e}$ & $73.33 \mathrm{~d}$ & $629.6 \mathrm{e}$ & $689.5 \mathrm{e}$ \\
\hline Monopotassium phosphate at $2000 \mathrm{mg} / \mathrm{l}$ & $81.55 \mathrm{~d}$ & $80.52 \mathrm{c}$ & $43.67 \mathrm{~d}$ & $74.67 d$ & $631.7 \mathrm{~d}$ & $706.2 \mathrm{~d}$ \\
\hline Di-potassium hydrogen phosphate at $2000 \mathrm{mg} / \mathrm{l}$ & $79.97 \mathrm{~d}$ & $77.15 \mathrm{~d}$ & $46.67 \mathrm{c}$ & $76.67 \mathrm{c}$ & $640.9 \mathrm{c}$ & $720.5 \mathrm{c}$ \\
\hline
\end{tabular}

Means accompanied by numerous letters are considerably different at the stage at $\mathbf{P} \leq \mathbf{0 . 5}$ level according to Duncan's multiple range test (Duncan, 1955). 
Table 3. Effect of foliar application of different potassium sources on dry weight of herbs (g /plant), dry weight of herbs and flowers ( $g$ /plant) and total dry yield (herb and flowers) /season /feddan (ton) of Achillea millefolium L. plant during 2018/2019 and 2019/2020 seasons.

\begin{tabular}{|c|c|c|c|c|c|}
\hline \multirow[t]{2}{*}{ Treatments } & \multicolumn{2}{|c|}{$\begin{array}{c}\text { Dry weight of herbs } \\
\text { (g/plant) }\end{array}$} & \multicolumn{2}{|c|}{$\begin{array}{l}\text { Dry weight of herbs } \\
\text { and flowers (g } \\
\text { /plant) }\end{array}$} & \multirow{2}{*}{$\begin{array}{c}\text { Total dry yield } \\
\text { (herb and flowers) } \\
\text { /season /feddan (ton) }\end{array}$} \\
\hline & $1^{\text {st }}$ cut & $2^{\text {nd }}$ cut & $1^{\text {st }}$ cut & $2^{\text {nd }}$ cut & \\
\hline & \multicolumn{5}{|c|}{ First season $(2018 / 2019)$} \\
\hline Control (tap water) at $0 \mathrm{mg} / \mathrm{l}$ & $97.53 \mathrm{i}$ & $102.7 \mathrm{i}$ & $104.2 \mathrm{~h}$ & $110.0 \mathrm{~g}$ & $2.40 \mathrm{i}$ \\
\hline Potassium chloride at $2000 \mathrm{mg} / \mathrm{l}$ & $106.3 \mathrm{~h}$ & $113.0 \mathrm{~h}$ & $114.0 \mathrm{~g}$ & $121.2 \mathrm{f}$ & $2.63 \mathrm{~h}$ \\
\hline Potassium citrate at $2000 \mathrm{mg} / \mathrm{l}$ & $129.2 \mathrm{~g}$ & $146.1 \mathrm{~g}$ & $138.6 \mathrm{f}$ & $157.1 \mathrm{e}$ & $3.31 \mathrm{~g}$ \\
\hline Potassium humate at 2000 mg/l & $157.6 \mathrm{~b}$ & $175.3 \mathrm{~b}$ & $172.5 \mathrm{~b}$ & $192.3 \mathrm{~b}$ & $4.09 \mathrm{~b}$ \\
\hline Potassium nitrate at $2000 \mathrm{mg} / \mathrm{l}$ & $161.2 \mathrm{a}$ & $183.8 \mathrm{a}$ & $177.8 \mathrm{a}$ & $202.8 \mathrm{a}$ & $4.26 \mathrm{a}$ \\
\hline Potassium silicate at $2000 \mathrm{mg} / \mathrm{l}$ & $132.9 \mathrm{f}$ & $148.1 \mathrm{f}$ & $141.4 \mathrm{e}$ & $158.2 \mathrm{e}$ & $3.36 \mathrm{f}$ \\
\hline Potassium sulphate at 2000 mg/l & $146.9 \mathrm{~d}$ & $154.2 \mathrm{~d}$ & $156.9 \mathrm{~d}$ & $165.6 \mathrm{~d}$ & $3.61 \mathrm{~d}$ \\
\hline Monopotassium phosphate at $2000 \mathrm{mg} / \mathrm{l}$ & $144.9 \mathrm{e}$ & $151.8 \mathrm{e}$ & $155.8 \mathrm{~d}$ & $164.0 \mathrm{~d}$ & $3.58 \mathrm{e}$ \\
\hline Di-potassium hydrogen phosphate at $2000 \mathrm{mg} / \mathrm{l}$ & $152.0 \mathrm{c}$ & $164.0 \mathrm{c}$ & $164.1 \mathrm{c}$ & 177.9 & $3.83 \mathrm{c}$ \\
\hline
\end{tabular}

Second season $(2019 / 2020)$

\begin{tabular}{|c|c|c|c|c|c|}
\hline Control (tap water) at $0 \mathrm{mg} / \mathrm{l}$ & $101.1 \mathrm{~h}$ & $109.3 \mathrm{~h}$ & $107.5 \mathrm{~h}$ & $116.6 \mathrm{i}$ & $2.51 \mathrm{i}$ \\
\hline Potassium chloride at $2000 \mathrm{mg} / \mathrm{l}$ & $112.3 \mathrm{~g}$ & $122.8 \mathrm{~g}$ & $119.8 \mathrm{~g}$ & $131.4 \mathrm{~h}$ & $2.81 \mathrm{~h}$ \\
\hline Potassium citrate at $2000 \mathrm{mg} / \mathrm{l}$ & $134.0 \mathrm{e}$ & $152.1 \mathrm{e}$ & $144.9 \mathrm{e}$ & $165.2 \mathrm{f}$ & $3.47 \mathrm{f}$ \\
\hline Potassium humate at $2000 \mathrm{mg} / \mathrm{l}$ & $160.2 \mathrm{~b}$ & $181.9 \mathrm{~b}$ & $175.8 \mathrm{~b}$ & $199.6 \mathrm{~b}$ & $4.21 \mathrm{~b}$ \\
\hline Potassium nitrate at $2000 \mathrm{mg} / \mathrm{l}$ & $165.2 \mathrm{a}$ & $188.7 \mathrm{a}$ & $182.5 \mathrm{a}$ & $208.3 \mathrm{a}$ & $4.38 \mathrm{a}$ \\
\hline Potassium silicate at $2000 \mathrm{mg} / \mathrm{l}$ & $129.3 \mathrm{f}$ & $149.7 \mathrm{f}$ & $139.3 \mathrm{f}$ & $161.0 \mathrm{~g}$ & $3.36 \mathrm{~g}$ \\
\hline Potassium sulphate at $2000 \mathrm{mg} / \mathrm{l}$ & $151.5 \mathrm{~d}$ & $160.2 \mathrm{~d}$ & $162.7 \mathrm{~d}$ & $172.0 \mathrm{e}$ & $3.75 \mathrm{e}$ \\
\hline Monopotassium phosphate at $2000 \mathrm{mg} / \mathrm{l}$ & $150.5 \mathrm{~d}$ & $160.4 \mathrm{~d}$ & $162.1 \mathrm{~d}$ & $174.6 \mathrm{~d}$ & $3.77 \mathrm{~d}$ \\
\hline Di-potassium hydrogen phosphate at $2000 \mathrm{mg} / \mathrm{l}$ & $156.8 \mathrm{c}$ & $171.1 \mathrm{c}$ & $169.5 \mathrm{c}$ & $188.0 \mathrm{c}$ & $4.00 \mathrm{c}$ \\
\hline
\end{tabular}

Means accompanied by numerous letters are considerably different at the stage at $P \leq 0.5$ level according to Duncan's multiple range test (Duncan, 1955). 
during stomatal activity, $\mathrm{K}$ leads a key role in the control of turgor beyond, within, guard cells. Potassium is an essential nutrient for meristematic plant growth and physiological functions, including plant water and gas exchange control, protein synthesis, activation of enzymes, photosynthesis and translocation of carbohydrates in plants. In addition, $\mathrm{K}$ is also important for the success of multiple functions of plant enzymes and controls higher plant metabolite trends, gradually changing metabolite concentrations. (Mengel and Kirkby, 2001 and Marschner, 2012). Foliar supply of $\mathrm{KNO}_{3}$ to the improve $\mathrm{K}$ and $\mathrm{N}$ status of salt treated plants. The role of potassium in ionic balance is reflected in nitrate metabolism (Jeschke and Wolf, 1985). A necessary factor for plant growth is nitrogen, which is an active component of chlorophyll and protein. Potassium spray results in an increase in the content of leaf potassium, followed by increased amounts of photosynthesis, photorespiration and carboxylase activity of RuBP. Therefore, in the latest inquiry, there was a substantial increase in development and under the saline strata. Ebert et al. (2002) found that supplying of $\mathrm{Ca}\left(\mathrm{NO}_{3}\right)_{2}$ at $10 \mathrm{mM}$ had a beneficial effect on growth and metabolism of $\mathrm{NaCl}$ treated guava seedlings. Akram et al. (2009) declared that, improvement in sunflower development due to foliar spray of $\mathrm{K}_{2} \mathrm{SO}_{4}$ and $\mathrm{KNO}_{3}$ was observed at $1.25 \%$ under saline concentrations of $150 \mathrm{mM}$ $\mathrm{NaCl}$. The improving effect of potassium humate or potassium silicate on vegetative growth traits at different concentrations may be due to the beneficial effect of potassium and silicon or potassium and humic acid being mixed.

Where potassium plays an important role in osmoregulation, photosynthesis, transpiration, stomatal opening and closing, protein synthesis, assimilates are converted into sink organs and enzymes are formed. (Mengel and Kirkby, 2001; Cakmak, 2005; Milford and Johnston, 2007). In addition, silicon's successful function in the plant is to enhance the architecture to reveal more erect leaves that intercept higher solar luminosity, increasing photosynthetic efficiency and higher chlorophyll material. (Braga et al., 2009), Besides its role in plant forbearance, several stress factors are associated with it. The strengthening effect of humic acid on pea vegetative growth may be due to the introduction of plant hormones that have a beneficial effect on plant nutrition. (Martinez et al., 1983) and enhance the uptake of minerals through the stimulation of microbiological activity (Akinremi et al., 2000). The obtained results are in harmony with those reported by Said-Al Ahl et al. (2009) on of oregano plants, Jabeen and Ahmad (2011) on sunflower and safflower plants, Matin et al. (2015) on Narcissus tazetta plants, Basiouny (2020) on Taxoduim disticum plant and Swietenia mahagoni plant, Ghatas and Mohamed (2020) demonstrated that, monopotassium phosphate with EM or phosphorein were the best for improving growth parameters of Oenothera biennis L. plant and Moghith et al. (2020) reported that the maximum growth parameters of the chia (Salvia hispanica L.) plant have been shown to be preferred for cultivation under saline water irrigation at $\left(0.68 \mathrm{dSm}^{-1}\right)$ and potassium silicate spray at 2000 ppm.

$\mathrm{K}$ foliar feeding has shown that supplementary feeding at critical stages of growth will increase performance and quality. Compared to both $\mathrm{K}$-applied as $\mathrm{KCl}$ and power, foliar-applied $\mathrm{K}$ in the form of $\mathrm{KNO}_{3}$ showed more yield compared to Kapplied as $\mathrm{KCl}$ (Oosterhuis et al., 1993).

\section{Flowering parameters:}

Various potassium sources had significant effects on number of inflorescences, fresh weight of flowers (g/plant), dry weight of flowers (g/plant), dry weights of herbs and flowers (g/plant) and total dry yield (herbs and flowers)/season/ feddan (ton) of yarrow plant (Tables, 3 and 4). The maximum values of parameters mentioned afore were observed for potassium nitrate followed by potassium humate as compared with the control. Moreover, di-potassium hydrogen phosphate 
Table 4. Effect of foliar application of different potassium sources on number of inflorescences, Fresh weight of flowers (g /plant) and dry weight of flowers (g/plant) of Achillea millefolium L. plant during 2018/2019 and 2019/2020 seasons.

\begin{tabular}{|c|c|c|c|c|c|c|}
\hline \multirow{2}{*}{ Treatments } & \multicolumn{2}{|c|}{$\begin{array}{l}\text { Number of } \\
\text { inflorescences }\end{array}$} & \multicolumn{2}{|c|}{$\begin{array}{c}\text { Fresh weight of } \\
\text { flowers (g /plant) }\end{array}$} & \multicolumn{2}{|c|}{$\begin{array}{c}\text { Dry weight of } \\
\text { flowers (g/plant) }\end{array}$} \\
\hline & $1^{\text {st }}$ cut & $2^{\text {nd }}$ cut & $1^{\text {st }}$ cut & $2^{\text {nd }}$ cut & $1^{\text {st }}$ cut & $2^{\text {nd }}$ cut \\
\hline & \multicolumn{6}{|c|}{ First season $(2018 / 2019)$} \\
\hline Control (tap water) at $0 \mathrm{mg} / \mathrm{l}$ & $23.0 \mathrm{i}$ & $43.33 \mathrm{~h}$ & $40.89 \mathrm{i}$ & $49.57 \mathrm{~g}$ & $6.64 \mathrm{i}$ & $7.30 \mathrm{~h}$ \\
\hline Potassium chloride at $2000 \mathrm{mg} / \mathrm{l}$ & $28.33 \mathrm{~h}$ & $50.00 \mathrm{~g}$ & $48.66 \mathrm{~h}$ & $59.40 \mathrm{f}$ & $7.68 \mathrm{~h}$ & $8.17 \mathrm{~g}$ \\
\hline Potassium citrate at $2000 \mathrm{mg} / \mathrm{l}$ & $32.67 \mathrm{~g}$ & $63.67 \mathrm{f}$ & $65.85 \mathrm{f}$ & $70.67 \mathrm{e}$ & $9.45 \mathrm{f}$ & $11.03 \mathrm{e}$ \\
\hline Potassium humate at $2000 \mathrm{mg} / \mathrm{l}$ & $49.67 \mathrm{~b}$ & $82.67 \mathrm{~b}$ & $77.48 \mathrm{~b}$ & $87.89 \mathrm{a}$ & $14.95 \mathrm{~b}$ & $17.00 \mathrm{~b}$ \\
\hline Potassium nitrate at $2000 \mathrm{mg} / \mathrm{l}$ & $57.00 \mathrm{a}$ & 88.67 a & $83.77 \mathrm{a}$ & $89.81 \mathrm{a}$ & $16.59 \mathrm{a}$ & $18.95 \mathrm{a}$ \\
\hline Potassium silicate at $2000 \mathrm{mg} / \mathrm{l}$ & $35.67 \mathrm{f}$ & $69.67 \mathrm{e}$ & $64.14 \mathrm{~g}$ & $68.66 \mathrm{e}$ & $8.58 \mathrm{~g}$ & $10.07 \mathrm{f}$ \\
\hline Potassium sulphate at $2000 \mathrm{mg} / \mathrm{l}$ & $37.67 \mathrm{e}$ & $75.0 \mathrm{c}$ & $68.37 \mathrm{e}$ & $75.26 \mathrm{~d}$ & $10.0 \mathrm{e}$ & $11.36 \mathrm{e}$ \\
\hline Monopotassium phosphate at $2000 \mathrm{mg} / \mathrm{l}$ & $39.67 \mathrm{~d}$ & $72.0 \mathrm{~d}$ & $70.07 \mathrm{~d}$ & $79.47 \mathrm{c}$ & $10.89 \mathrm{~d}$ & $12.21 \mathrm{~d}$ \\
\hline \multirow[t]{2}{*}{ Di-potassium hydrogen phosphate at $2000 \mathrm{mg} / \mathrm{l}$} & $43.67 \mathrm{c}$ & $76.33 \mathrm{c}$ & $74.22 \mathrm{c}$ & $84.64 \mathrm{~b}$ & $12.07 \mathrm{c}$ & $13.91 \mathrm{c}$ \\
\hline & \multicolumn{6}{|c|}{ Second season $(2019 / 2020)$} \\
\hline Control (tap water) at $0 \mathrm{mg} / \mathrm{l}$ & $25.67 \mathrm{~h}$ & $46.67 \mathrm{~h}$ & $43.88 \mathrm{i}$ & $50.57 \mathrm{i}$ & $6.47 \mathrm{~g}$ & $7.26 \mathrm{~h}$ \\
\hline Potassium chloride at $2000 \mathrm{mg} / \mathrm{l}$ & $31.67 \mathrm{~g}$ & $54.67 \mathrm{~g}$ & $49.33 \mathrm{~h}$ & $60.61 \mathrm{~h}$ & $7.43 \mathrm{f}$ & $8.57 \mathrm{~g}$ \\
\hline Potassium citrate at $2000 \mathrm{mg} / \mathrm{l}$ & $35.67 \mathrm{f}$ & $63.67 \mathrm{f}$ & $69.74 \mathrm{f}$ & $78.00 \mathrm{f}$ & $10.98 \mathrm{~d}$ & $13.17 \mathrm{e}$ \\
\hline Potassium humate at $2000 \mathrm{mg} / \mathrm{l}$ & $54.33 \mathrm{~b}$ & $86.67 \mathrm{~b}$ & $83.96 \mathrm{~b}$ & $90.75 \mathrm{~b}$ & $15.59 \mathrm{~b}$ & $17.78 \mathrm{~b}$ \\
\hline Potassium nitrate at $2000 \mathrm{mg} / \mathrm{l}$ & 60.33 a & $90.0 \mathrm{a}$ & $89.45 \mathrm{a}$ & $94.25 \mathrm{a}$ & $17.29 \mathrm{a}$ & $19.52 \mathrm{a}$ \\
\hline Potassium silicate at $2000 \mathrm{mg} / \mathrm{l}$ & $37.00 \mathrm{f}$ & $69.67 \mathrm{e}$ & $68.52 \mathrm{~g}$ & $74.0 \mathrm{~g}$ & $10.0 \mathrm{e}$ & $11.30 \mathrm{f}$ \\
\hline Potassium sulphate at $2000 \mathrm{mg} / \mathrm{l}$ & $40.67 \mathrm{e}$ & $74.67 \mathrm{~d}$ & $73.97 \mathrm{e}$ & $81.11 \mathrm{e}$ & $11.25 \mathrm{~d}$ & $11.77 \mathrm{f}$ \\
\hline Monopotassium phosphate at $2000 \mathrm{mg} / \mathrm{l}$ & $43.33 \mathrm{~d}$ & $76.33 \mathrm{~d}$ & $76.55 \mathrm{~d}$ & $84.22 \mathrm{~d}$ & $11.59 \mathrm{~d}$ & $14.26 \mathrm{~d}$ \\
\hline Di-potassium hydrogen phosphate at $2000 \mathrm{mg} / \mathrm{l}$ & $49.00 \mathrm{c}$ & $80.67 \mathrm{c}$ & $80.40 \mathrm{c}$ & $86.88 \mathrm{c}$ & $12.71 \mathrm{c}$ & $16.94 \mathrm{c}$ \\
\hline
\end{tabular}

Means accompanied by numerous letters are considerably different at the stage at $\mathbf{P} \leq \mathbf{0 . 5}$ level according to Duncan's multiple range test (Duncan, 1955). 
was ranked the third values in most cases in this concern.

\section{Chemical composition:}

\section{N, P, K, total chlorophylls and total carbohydrate content:}

Data in Tables (5 and 6) state that N, P, $\mathrm{K}$, total chlorophylls and total carbohydrate content in Achillea millefolium L. were increased by all different treatments for potassium sources. In this respect, the richest leaf $\mathrm{N}$ was resulted by potassium nitrate followed by potassium humate as compared with the control. Whereas, spraying Achillea millefolium L. plants with monopotassium phosphate treatment induced the highest values of the percentage of $\mathrm{P}$ and total chlorophylls content followed by dipotassium hydrogen phosphate. Moreover, the maximum $\mathrm{K} \%$ and total carbohydrate content were given by potassium sulphate followed by potassium silicate as compared with the other ones in most cases. The minimum values of these traits were the untreated plants.

The beneficial effect on chemical constituents in the leaves of various sources of potassium at different rates may be due to the same factors that have triggered vegetative growth, yields and their components as previously described. These findings are in harmony with those of SaidAl Ahl et al. (2009) on of oregano plants, Jabeen and Ahmad (2011) on sunflower and safflower plants, Basiouny (2020) on Taxoduim disticum plant and Swietenia mahagoni plant. Ghatas and Mohamed (2020) mentioned that, monopotassium phosphate with EM or phosphorein were the best for improving chemical constituents of Oenothera biennis L. plant. Moghith et al. (2020) It was shown that the combination therapy reported maximum $\mathrm{N}, \mathrm{P}$ and $\mathrm{K}$ content values of the chia (Salvia hispanica L.) plant between $0.68 \mathrm{dSm}^{-1}$ salinity concentration and $2000 \mathrm{ppm}$ potassium silicate.

\section{Oil yield parameters:}

According to the data referred to in Tables (7 and 8) it can be shown that, essential oil \%, essential oil yield/plant (ml), essential oil yield/plant of two cuts $(\mathrm{ml})$ and essential oil yield/feddan (1) of yarrow plant were more affected by using various potassium sources treatments as compared to control plants in the two cuts and seasons. In this respect, spraying Achillea millefolium L. plants with potassium citrate treatment induced the maximum values of parameters mentioned afore. However, the second and the third values of these parameters were recorded by the silicate phosphate and dipotassium hydrogen phosphate in $1^{\text {st }}$ cutting and $2^{\text {nd }}$ cutting as well as the first and second seasons, respectively in most cases. The lowest value of essential oil parameters was produced by control plants at both cuts and in the two seasons.

The enhanced impact of treatment with potassium silicate and potassium citrate may be attributed to the function of potassium in osmoregulation, photosynthesis, transpiration, stomatal opening and closing, protein synthesis, assimilate translocation, and enzyme activation (Mengel and Kirkby, 2001; Cakmak, 2005 and Milford and Johnston, 2007). In addition, the beneficial effects of silicon in facilitating plants live under conditions of water scarcity, reducing transpiration, development of plants, stable and competitive growth and productivity (Gao et al., 2006; Regina and Katarzyna, 2011). Obtained findings are in compliance by those reported by Abd El-Razik et al. (2015) illustrated that, combining the irrigation cycles with the application of potassium silicate, it was evident that the treatments had a marked impact on the quality of essential oil (percent) during all cuts of the chervil plant in both seasons. Miri et al. (2015) demonstrated that, the foliar application of citric acid greatly increased the vegetative properties of the thyme plant as well as the content of pigments (chlorophyll a and carotenoids) and essential oil output. Moghith (2019) declared that the 
Table 5. Effect of foliar application of different potassium sources on $\mathrm{N}, \mathrm{P}$ and $\mathrm{K} \%$ of Achillea millefolium $\mathrm{L}$. plant during 2018/2019 and 2019/2020 seasons.

\begin{tabular}{|c|c|c|c|c|c|c|}
\hline \multirow{2}{*}{ Treatments } & \multicolumn{2}{|c|}{$\mathbf{N} \%$} & \multicolumn{2}{|c|}{$\mathbf{P} \%$} & \multicolumn{2}{|c|}{$\mathbf{K} \%$} \\
\hline & $1^{\text {st }}$ cut & $2^{\text {nd }}$ cut & $1^{\text {st }}$ cut & $2^{\text {nd }}$ cut & $1^{\text {st }}$ cut & $2^{\text {nd }} \mathrm{cu}$ \\
\hline & \multicolumn{6}{|c|}{ First season $(2018 / 2019)$} \\
\hline Control (tap water) at $0 \mathrm{mg} / \mathrm{l}$ & $1.96 \mathrm{~h}$ & $2.14 \mathrm{~h}$ & $0.231 \mathrm{~h}$ & $0.239 \mathrm{~h}$ & $1.70 \mathrm{~g}$ & $1.72 \mathrm{i}$ \\
\hline Potassium chloride at $2000 \mathrm{mg} / \mathrm{l}$ & $2.14 \mathrm{~g}$ & $2.29 \mathrm{~g}$ & $0.240 \mathrm{~g}$ & $0.245 \mathrm{~g}$ & $1.80 \mathrm{f}$ & $1.89 \mathrm{~h}$ \\
\hline Potassium citrate at $2000 \mathrm{mg} / \mathrm{l}$ & $2.39 \mathrm{e}$ & $2.41 \mathrm{f}$ & $0.249 \mathrm{f}$ & $0.254 \mathrm{e}$ & $2.24 \mathrm{~d}$ & $2.13 \mathrm{~g}$ \\
\hline Potassium humate at $2000 \mathrm{mg} / \mathrm{l}$ & $3.0 \mathrm{~b}$ & $3.12 \mathrm{~b}$ & $0.253 \mathrm{e}$ & $0.260 \mathrm{~d}$ & $2.18 \mathrm{e}$ & $2.23 \mathrm{f}$ \\
\hline Potassium nitrate at $2000 \mathrm{mg} / \mathrm{l}$ & $3.09 \mathrm{a}$ & $3.20 \mathrm{a}$ & $0.260 \mathrm{~d}$ & $0.262 \mathrm{~d}$ & $2.30 \mathrm{c}$ & $2.35 \mathrm{c}$ \\
\hline Potassium silicate at $2000 \mathrm{mg} / \mathrm{l}$ & $2.33 \mathrm{f}$ & $2.41 \mathrm{f}$ & $0.249 \mathrm{f}$ & $0.249 \mathrm{f}$ & $2.38 \mathrm{~b}$ & $2.40 \mathrm{~b}$ \\
\hline Potassium sulphate at $2000 \mathrm{mg} / \mathrm{l}$ & $2.44 \mathrm{e}$ & $2.59 \mathrm{e}$ & $0.269 \mathrm{c}$ & $0.277 \mathrm{c}$ & $2.40 \mathrm{a}$ & $2.45 \mathrm{a}$ \\
\hline Monopotassium phosphate at $2000 \mathrm{mg} / \mathrm{l}$ & $2.60 \mathrm{~d}$ & $2.71 \mathrm{~d}$ & $0.282 \mathrm{a}$ & $0.290 \mathrm{a}$ & $2.23 \mathrm{~d}$ & $2.31 \mathrm{~d}$ \\
\hline \multirow[t]{2}{*}{ Di-potassium hydrogen phosphate at $2000 \mathrm{mg} / \mathrm{l}$} & $2.79 \mathrm{c}$ & $2.88 \mathrm{c}$ & $0.276 \mathrm{~b}$ & $0.286 \mathrm{~b}$ & $2.19 \mathrm{e}$ & $2.25 \mathrm{e}$ \\
\hline & \multicolumn{6}{|c|}{ Second season $(2019 / 2020)$} \\
\hline Control (tap water) at $0 \mathrm{mg} / \mathrm{l}$ & $1.82 \mathrm{i}$ & $2.08 \mathrm{~h}$ & $0.231 \mathrm{~g}$ & $0.239 \mathrm{f}$ & $1.72 \mathrm{i}$ & $1.76 \mathrm{i}$ \\
\hline Potassium chloride at $2000 \mathrm{mg} / \mathrm{l}$ & $2.03 \mathrm{~h}$ & $2.30 \mathrm{~g}$ & $0.240 \mathrm{f}$ & $0.246 \mathrm{e}$ & $1.89 \mathrm{~h}$ & $1.95 \mathrm{~h}$ \\
\hline Potassium citrate at $2000 \mathrm{mg} / \mathrm{l}$ & $2.41 \mathrm{f}$ & $2.53 \mathrm{f}$ & $0.260 \mathrm{~cd}$ & $0.265 \mathrm{~cd}$ & $2.25 \mathrm{f}$ & $2.19 \mathrm{~g}$ \\
\hline Potassium humate at $2000 \mathrm{mg} / \mathrm{l}$ & $2.98 \mathrm{~b}$ & $3.04 \mathrm{~b}$ & $0.258 \mathrm{de}$ & $0.261 \mathrm{~d}$ & $2.22 \mathrm{~g}$ & $2.25 \mathrm{f}$ \\
\hline Potassium nitrate at $2000 \mathrm{mg} / \mathrm{l}$ & $3.14 \mathrm{a}$ & $3.22 \mathrm{a}$ & $0.263 \mathrm{c}$ & $0.266 \mathrm{c}$ & $2.38 \mathrm{c}$ & $2.37 \mathrm{c}$ \\
\hline Potassium silicate at $2000 \mathrm{mg} / \mathrm{l}$ & $2.35 \mathrm{~g}$ & $2.50 \mathrm{f}$ & $0.254 \mathrm{e}$ & $0.260 \mathrm{~d}$ & $2.40 \mathrm{a}$ & $2.39 \mathrm{~b}$ \\
\hline Potassium sulphate at $2000 \mathrm{mg} / \mathrm{l}$ & $2.49 \mathrm{e}$ & $2.70 \mathrm{e}$ & $0.276 \mathrm{~b}$ & $0.286 \mathrm{~b}$ & $2.39 \mathrm{~b}$ & $2.48 \mathrm{a}$ \\
\hline Monopotassium phosphate at $2000 \mathrm{mg} / \mathrm{l}$ & $2.71 \mathrm{~d}$ & $2.82 \mathrm{~d}$ & $0.290 \mathrm{a}$ & $0.296 \mathrm{a}$ & $2.30 \mathrm{~d}$ & $2.31 \mathrm{~d}$ \\
\hline Di-potassium hydrogen phosphate at $2000 \mathrm{mg} / \mathrm{l}$ & $2.88 \mathrm{c}$ & $2.92 \mathrm{c}$ & $0.287 \mathrm{a}$ & $0.290 \mathrm{~b}$ & $2.27 \mathrm{e}$ & $2.29 \mathrm{e}$ \\
\hline
\end{tabular}

Means accompanied by numerous letters are considerably different at the stage at $\mathbf{P} \leq \mathbf{0 . 5}$ level according to Duncan's multiple range test (Duncan, 1955). 
Table 6. Effect of foliar application of different potassium sources on total chlorophylls (mg/100 $\mathrm{g}$ f.w.) and total carbohydrates (\%) of Achillea millefolium L. plant during 2018/2019 and 2019/2020 seasons.

\begin{tabular}{|c|c|c|c|c|}
\hline \multirow{2}{*}{ Treatments } & \multicolumn{2}{|c|}{$\begin{array}{l}\text { Total chlorophylls } \\
\text { (mg/100 g f.w.) }\end{array}$} & \multicolumn{2}{|c|}{$\begin{array}{c}\text { Total carbohydrates } \\
\text { (\%) }\end{array}$} \\
\hline & $1^{\text {st }}$ cut & $2^{\text {nd }}$ cut & $1^{\text {st }}$ cut & $2^{\text {nd }}$ cut \\
\hline & \multicolumn{4}{|c|}{ First season $(2018 / 2019)$} \\
\hline Control (tap water) at $0 \mathrm{mg} / \mathrm{l}$ & $161.2 \mathrm{~h}$ & $170.9 \mathrm{i}$ & $13.78 \mathrm{f}$ & $14.17 \mathrm{e}$ \\
\hline Potassium chloride at $2000 \mathrm{mg} / \mathrm{l}$ & $173.5 \mathrm{fg}$ & $175.4 \mathrm{~h}$ & $14.07 \mathrm{f}$ & $14.71 \mathrm{e}$ \\
\hline Potassium citrate at $2000 \mathrm{mg} / \mathrm{l}$ & $174.2 \mathrm{f}$ & $177.7 \mathrm{~g}$ & $14.97 \mathrm{e}$ & $15.65 \mathrm{~d}$ \\
\hline Potassium humate at $2000 \mathrm{mg} / \mathrm{l}$ & $184.3 \mathrm{~d}$ & $180.8 \mathrm{e}$ & $15.23 \mathrm{e}$ & $16.13 \mathrm{~d}$ \\
\hline Potassium nitrate at $2000 \mathrm{mg} / \mathrm{l}$ & $180.8 \mathrm{e}$ & $184.0 \mathrm{~d}$ & $17.88 \mathrm{c}$ & $17.26 \mathrm{c}$ \\
\hline Potassium silicate at $2000 \mathrm{mg} / \mathrm{l}$ & $172.4 \mathrm{~g}$ & $179.2 \mathrm{f}$ & $19.87 \mathrm{~b}$ & $19.19 \mathrm{~b}$ \\
\hline Potassium sulphate at $2000 \mathrm{mg} / \mathrm{l}$ & $187.5 \mathrm{c}$ & $189.9 \mathrm{c}$ & 20.98 a & $21.95 \mathrm{a}$ \\
\hline Monopotassium phosphate at $2000 \mathrm{mg} / \mathrm{l}$ & $198.5 \mathrm{a}$ & $201.0 \mathrm{a}$ & $16.47 \mathrm{~d}$ & $17.27 \mathrm{c}$ \\
\hline \multirow[t]{2}{*}{ Di-potassium hydrogen phosphate at $2000 \mathrm{mg} / \mathrm{l}$} & $190.9 \mathrm{~b}$ & $196.1 \mathrm{~b}$ & $15.34 \mathrm{e}$ & $15.90 \mathrm{~d}$ \\
\hline & \multicolumn{4}{|c|}{ Second season $(2019 / 2020)$} \\
\hline Control (tap water) at $0 \mathrm{mg} / \mathrm{l}$ & $163.4 \mathrm{~h}$ & $165.7 \mathrm{i}$ & $13.32 \mathrm{f}$ & $14.46 \mathrm{~h}$ \\
\hline Potassium chloride at $2000 \mathrm{mg} / \mathrm{l}$ & $170.3 \mathrm{~g}$ & $173.4 \mathrm{~h}$ & $14.26 \mathrm{f}$ & $15.17 \mathrm{gh}$ \\
\hline Potassium citrate at $2000 \mathrm{mg} / \mathrm{l}$ & $175.5 \mathrm{f}$ & $180.2 \mathrm{~g}$ & $15.66 \mathrm{e}$ & $16.49 \mathrm{ef}$ \\
\hline Potassium humate at $2000 \mathrm{mg} / \mathrm{l}$ & $178.6 \mathrm{e}$ & $185.9 \mathrm{e}$ & $16.09 \mathrm{de}$ & $15.92 \mathrm{fg}$ \\
\hline Potassium nitrate at $2000 \mathrm{mg} / \mathrm{l}$ & $181.0 \mathrm{~d}$ & $188.2 \mathrm{~d}$ & $18.87 \mathrm{~b}$ & $19.14 \mathrm{c}$ \\
\hline Potassium silicate at $2000 \mathrm{mg} / \mathrm{l}$ & $179.1 \mathrm{e}$ & $182.1 \mathrm{f}$ & $19.94 \mathrm{~b}$ & $20.70 \mathrm{a}$ \\
\hline Potassium sulphate at $2000 \mathrm{mg} / \mathrm{l}$ & $194.1 \mathrm{c}$ & $198.1 \mathrm{c}$ & $21.25 \mathrm{a}$ & $22.99 \mathrm{a}$ \\
\hline Monopotassium phosphate at $2000 \mathrm{mg} / \mathrm{l}$ & $201.1 \mathrm{a}$ & $202.4 \mathrm{a}$ & $17.54 \mathrm{c}$ & $18.04 \mathrm{~d}$ \\
\hline Di-potassium hydrogen phosphate at $2000 \mathrm{mg} / \mathrm{l}$ & 197.6 b & $200.7 \mathrm{~b}$ & $16.90 \mathrm{~cd}$ & $16.77 \mathrm{e}$ \\
\hline
\end{tabular}

Means accompanied by numerous letters are considerably different at the stage at $\mathbf{P} \leq \mathbf{0 . 5}$ level according to Duncan's multiple range test (Duncan, 1955). 
Table 7. Effect of foliar application of different potassium sources on essential oil (\%) and essential oil yield/plant $(\mathrm{ml})$ of Achillea millefolium L. plant during 2018/2019 and 2019/2020 seasons.

\begin{tabular}{|c|c|c|c|c|}
\hline \multirow[t]{2}{*}{ Treatments } & \multicolumn{2}{|c|}{$\begin{array}{l}\text { Essential oil } \\
\qquad(\%)\end{array}$} & \multicolumn{2}{|c|}{$\begin{array}{l}\text { Essential oil yield/plant } \\
\text { (ml) }\end{array}$} \\
\hline & $1^{\text {st }}$ cut & $2^{\text {nd }}$ cut & $1^{\text {st }}$ cut & $2^{\text {nd }}$ cut \\
\hline & \multicolumn{4}{|c|}{ First season $(2018 / 2019)$} \\
\hline Control (tap water) at 0 mg/l & $0.34 \mathrm{i}$ & $0.39 \mathrm{i}$ & $0.35 \mathrm{f}$ & $0.43 \mathrm{i}$ \\
\hline Potassium chloride at $2000 \mathrm{mg} / \mathrm{l}$ & $0.37 \mathrm{~h}$ & $0.43 \mathrm{~h}$ & $0.43 \mathrm{e}$ & $0.53 \mathrm{~h}$ \\
\hline Potassium citrate at $2000 \mathrm{mg} / \mathrm{l}$ & $0.70 \mathrm{a}$ & $0.81 \mathrm{a}$ & $0.96 \mathrm{a}$ & $1.28 \mathrm{a}$ \\
\hline Potassium humate at $2000 \mathrm{mg} / \mathrm{l}$ & $0.47 \mathrm{f}$ & $0.57 \mathrm{f}$ & $0.82 \mathrm{~cd}$ & $1.10 \mathrm{c}$ \\
\hline Potassium nitrate at $2000 \mathrm{mg} / \mathrm{l}$ & $0.45 \mathrm{~g}$ & $0.52 \mathrm{~g}$ & $0.79 \mathrm{~d}$ & $1.06 \mathrm{f}$ \\
\hline Potassium silicate at $2000 \mathrm{mg} / \mathrm{l}$ & $0.60 \mathrm{~b}$ & $0.79 \mathrm{~b}$ & $0.85 \mathrm{bc}$ & $1.24 \mathrm{~b}$ \\
\hline Potassium sulphate at $2000 \mathrm{mg} / \mathrm{l}$ & 0.49 e & $0.60 \mathrm{e}$ & $0.76 \mathrm{~d}$ & $0.99 \mathrm{~g}$ \\
\hline Monopotassium phosphate at 2000 mg/l & $0.57 \mathrm{c}$ & $0.65 \mathrm{c}$ & $0.89 \mathrm{~b}$ & $1.07 \mathrm{e}$ \\
\hline \multirow[t]{2}{*}{ Di-potassium hydrogen phosphate at $2000 \mathrm{mg} / \mathrm{l}$} & $0.50 \mathrm{~d}$ & $0.61 \mathrm{~d}$ & $0.82 \mathrm{~cd}$ & $1.09 \mathrm{~d}$ \\
\hline & \multicolumn{4}{|c|}{ Second season $(2019 / 2020)$} \\
\hline Control (tap water) at $0 \mathrm{mg} / \mathrm{l}$ & $0.36 \mathrm{~h}$ & $0.43 \mathrm{~h}$ & $0.39 \mathrm{i}$ & $0.50 \mathrm{~h}$ \\
\hline Potassium chloride at $2000 \mathrm{mg} / \mathrm{l}$ & $0.43 \mathrm{~g}$ & $0.45 \mathrm{~g}$ & $0.52 \mathrm{~h}$ & $0.60 \mathrm{~g}$ \\
\hline Potassium citrate at $2000 \mathrm{mg} / \mathrm{l}$ & $0.74 \mathrm{a}$ & $0.84 \mathrm{a}$ & $1.07 \mathrm{a}$ & $1.39 \mathrm{a}$ \\
\hline Potassium humate at $2000 \mathrm{mg} / \mathrm{l}$ & $0.53 \mathrm{e}$ & $0.61 \mathrm{e}$ & $0.94 \mathrm{e}$ & $1.21 \mathrm{~d}$ \\
\hline Potassium nitrate at $2000 \mathrm{mg} / \mathrm{l}$ & $0.50 \mathrm{f}$ & $0.52 \mathrm{f}$ & $0.91 \mathrm{f}$ & $1.09 \mathrm{e}$ \\
\hline Potassium silicate at $2000 \mathrm{mg} / \mathrm{l}$ & $0.69 \mathrm{~b}$ & $0.83 \mathrm{~b}$ & $0.96 \mathrm{~d}$ & $1.34 \mathrm{~b}$ \\
\hline Potassium sulphate at $2000 \mathrm{mg} / \mathrm{l}$ & $0.53 \mathrm{e}$ & $0.60 \mathrm{e}$ & $0.87 \mathrm{~g}$ & $1.04 \mathrm{f}$ \\
\hline Monopotassium phosphate at 2000 mg/l & $0.59 \mathrm{~d}$ & $0.62 \mathrm{~d}$ & $0.97 \mathrm{c}$ & $1.09 \mathrm{e}$ \\
\hline Di-potassium hydrogen phosphate at $2000 \mathrm{mg} / \mathrm{l}$ & $0.61 \mathrm{c}$ & $0.65 \mathrm{c}$ & $1.03 \mathrm{~b}$ & $1.23 \mathrm{c}$ \\
\hline
\end{tabular}

Means accompanied by numerous letters are considerably different at the stage at $P \leq 0.5$ level according to Duncan's multiple range test (Duncan, 1955). 
Table 8. Effect of foliar application of different potassium sources on essential oil yield/plant of two cuts (ml) and essential oil yield/feddan (l) of Achillea millefolium L. plant during 2018/2019 and 2019/2020 seasons.

\begin{tabular}{lcc}
\hline Treatments & $\begin{array}{c}\text { Essential oil yield/plant of two } \\
\text { cuts }(\mathrm{ml})\end{array}$ & $\begin{array}{c}\text { Essential oil yield/feddan } \\
\text { (l) }\end{array}$ \\
\hline
\end{tabular}

First season (2018/2019)

\begin{tabular}{|c|c|c|}
\hline Control (tap water) at $0 \mathrm{mg} / \mathrm{l}$ & $0.78 \mathrm{~g}$ & $8.77 \mathrm{~g}$ \\
\hline Potassium chloride at $2000 \mathrm{mg} / \mathrm{l}$ & $0.95 \mathrm{f}$ & $10.60 \mathrm{f}$ \\
\hline Potassium citrate at $2000 \mathrm{mg} / \mathrm{l}$ & $2.24 \mathrm{a}$ & $25.13 \mathrm{a}$ \\
\hline Potassium humate at $2000 \mathrm{mg} / \mathrm{l}$ & $1.92 \mathrm{~cd}$ & $21.50 \mathrm{~cd}$ \\
\hline Potassium nitrate at $2000 \mathrm{mg} / \mathrm{l}$ & $1.86 \mathrm{~d}$ & $20.78 \mathrm{~d}$ \\
\hline Potassium silicate at $2000 \mathrm{mg} / \mathrm{l}$ & $2.09 \mathrm{~b}$ & $23.49 \mathrm{~b}$ \\
\hline Potassium sulphate at $2000 \mathrm{mg} / \mathrm{l}$ & $1.75 \mathrm{e}$ & $19.62 \mathrm{e}$ \\
\hline Monopotassium phosphate at $2000 \mathrm{mg} / \mathrm{l}$ & $1.96 \mathrm{c}$ & $21.95 \mathrm{c}$ \\
\hline Di-potassium hydrogen phosphate at $2000 \mathrm{mg} / \mathrm{l}$ & $1.91 \mathrm{~cd}$ & 21.35 \\
\hline
\end{tabular}

Second season (2019/2020)

Control (tap water) at $0 \mathrm{mg} / \mathrm{l}$

$0.89 \mathrm{~h}$

$9.95 \mathrm{~h}$

Potassium chloride at 2000 mg/l

$1.12 \mathrm{~g}$

$12.48 \mathrm{~g}$

Potassium citrate at $2000 \mathrm{mg} / \mathrm{l}$

$2.46 \mathrm{a}$

$27.50 \mathrm{a}$

Potassium humate at 2000 mg/l

$2.15 \mathrm{c}$

$24.07 \mathrm{c}$

Potassium nitrate at 2000 mg/l

$2.0 \mathrm{e}$

$22.36 \mathrm{e}$

Potassium silicate at 2000 mg/l

$2.30 \mathrm{~b}$

$25.79 b$

Potassium sulphate at $2000 \mathrm{mg} / \mathrm{l}$

$1.91 \mathrm{f}$

$21.34 \mathrm{f}$

Monopotassium phosphate at $2000 \mathrm{mg} / \mathrm{l}$

$2.06 \mathrm{~d}$

$23.02 \mathrm{~d}$

Di-potassium hydrogen phosphate at $2000 \mathrm{mg} / \mathrm{l}$

$2.26 \mathrm{~b}$

$25.28 \mathrm{~b}$

Means accompanied by numerous letters are considerably different at the stage at $P \leq 0.5$ level according to Duncan's multiple range test (Duncan, 1955). 
richest percentage of oil and oil yield/chia plant (Salvia hispanica L.) seeds were graded with a concentration of $0.68 \mathrm{dSm}^{-1}$ saline water irrigation and potassium silicate spray at $2000 \mathrm{ppm}$, Farahani et al. (2020) declared that, the foliar application of $\mathrm{Si}$ at a concentration of 0.2 percent in spring and summer has been shown to be useful for increasing the essential oil content of rose oil, especially under conditions of water stress and Ghatas and Mohamed (2020) mentioned that, monopotassium phosphate with EM or phosphorein were the best for improving fixed oil productivity of Oenothera biennis L. plant.

Essential oil constituents of Achillea millefolium L. plant:

Table (9) and Figs. (1, 2, 3 and 4) illustrated that data foliar spraying with some potassium sources i.e. potassium nitrate, potassium silicate and potassium citrate at the same rates at $2000 \mathrm{mg} / \mathrm{l}$ in addition control treatment (tap water) at $0 \mathrm{mg} / \mathrm{l}$, the qualitative effects of the essential oil constituents of yarrow were greatly impacted. (Achillea millefolium L.) herbs and flowers. The essential oil constituents of Achillea millefolium L. thirteen components were recognized, produced, i.e., $\alpha$-pinene, myrcene, limonene, 1,8-cineole, $\mathrm{V}$-terpinene, linalool, camphor, borneol, carvacrol, thymol, linalyl acetate, chamazulene and $\alpha$ bisabolol oxide $B$. Hence, the main component was $\alpha$-bisabolol oxide B (34.41 to $50.10 \%$ ). The major components were $\alpha$ bisabolol oxide B (34.41 to $50.10 \%)$,

Table 9. Effect of foliar application of different potassium source on essential oil constituents of Achillea millefolium L. plant during the second cut and the second season 2019/2020.

\begin{tabular}{|c|c|c|c|c|c|}
\hline \multirow{2}{*}{$\begin{array}{l}\text { Peak } \\
\text { No. }\end{array}$} & \multirow[b]{2}{*}{ Components } & \multicolumn{4}{|c|}{ Area \% } \\
\hline & & $\begin{array}{c}\text { Control (tap } \\
\text { water) at } 0 \mathrm{mg} / \mathrm{l}\end{array}$ & $\begin{array}{l}\text { Potassium nitrate } \\
\text { at } 2000 \mathrm{mg} / \mathrm{l}\end{array}$ & $\begin{array}{l}\text { Potassium silicate } \\
\text { at } 2000 \mathrm{mg} / \mathrm{l}\end{array}$ & $\begin{array}{l}\text { Potassium citrate } \\
\text { at } 2000 \mathrm{mg} / \mathrm{l}\end{array}$ \\
\hline 1 & $\alpha$-Pinene & 2.44 & 0.10 & 0.68 & 3.32 \\
\hline 2 & Myrcene & 1.55 & 1.80 & 0.10 & 0.70 \\
\hline 3 & Limonene & 8.45 & 21.01 & 1.66 & 10.43 \\
\hline 4 & 1,8-Cineole & 5.15 & 9.11 & 3.59 & 6.73 \\
\hline 5 & V-Terpinene & - & 0.23 & 0.59 & 0.91 \\
\hline 6 & Linalool & - & 0.87 & 1.44 & 0.83 \\
\hline 7 & Camphor & 1.98 & 1.55 & 3.45 & 2.04 \\
\hline 8 & Borneol & 3.78 & 3.31 & 4.77 & 2.75 \\
\hline 9 & Carvacrol & 11.77 & 9.04 & 10.99 & 6.70 \\
\hline 10 & Thymol & 2.44 & 1.49 & 2.55 & 1.17 \\
\hline 11 & Linalyl acetate & 3.68 & 3.73 & 9.88 & 3.92 \\
\hline 12 & Chamazulene & 5.98 & 3.88 & 14.95 & 3.74 \\
\hline 13 & $\alpha$-Bisabolol oxide B & 34.41 & 35.46 & 37.27 & 50.10 \\
\hline & Total identified & 81.63 & 91.58 & 91.91 & 93.34 \\
\hline * & Unknown & 18.37 & 8.42 & 8.09 & 6.66 \\
\hline & Total & 100.00 & 100.00 & 100.00 & 100.00 \\
\hline
\end{tabular}



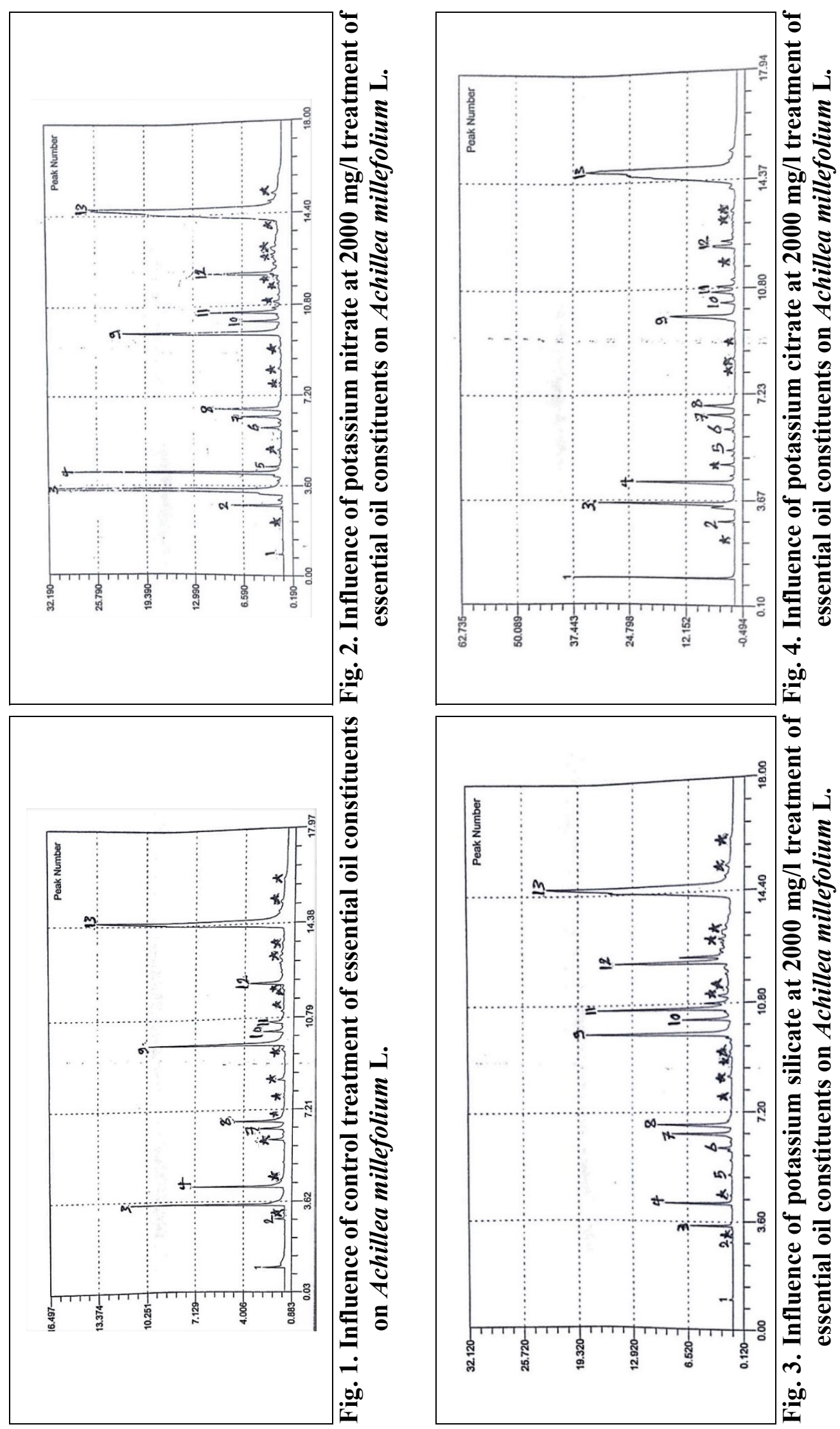
limonene (1.66 to $21.01 \%)$, carvacrol $(6.70$ to $11.77 \%$ ) and chamazulene (3.74 to $14.95 \%)$. The treatment of potassium citrate gave the maximum values of -bisabolol oxide B $(50.10 \%)$ followed descendingly by the treatment of potassium silicate as $(37.27 \%)$ when compared with control $(34.41 \%)$. Furthermore, the treatment of potassium nitrate scored the richest values limonene $(21.01 \%)$ followed descendingly by the treatment of potassium citrate as $(10.43 \%)$ whereas the lowest limonene vales $(1.66 \%)$ by the treatment of potassium silicate. On contrast, various treatments caused decreases in the percentage of carvacrol from (6.70 to $11.77 \%)$ in control to $10.99,9.04$ and $6.70 \%$ by foliar spray yarrow plant of the treatment potassium silicate, potassium nitrate, and potassium citrate, respectively. Additionally, the highest values of chamazulene $(14.95 \%)$ of yarrow was achieved by the treatment potassium silicate whereas the minimum values of the same component were recorded by treatment potassium citrate as (3.74\%). Achillea millefolium L. Mainly, essential oil comprises mono- and sesquiterpenoids. Pinenes, sabinene, phellandrene, eucalyptol (1,8-cineol), terpinen-4-ol and alphaterpineol were the most concentrated compounds in the first class, while the most important compounds in the second class were $\beta$-caryophyllene, bornyl acetate, eudesmol, camazulene, and alphabisabololol (Tuberoso and Kowalczyk, 2009; Rahimmalek et al., 2009; Bocevska and Sovová, 2007 and Chalchat et al., 1999). In this context, Turkmenoglu et al. (2015) demonstrated that the main constituents of the oil Achillea millefolium subsp. Millefolium $\alpha$-bisabolol (12\%), oxide of caryophyllene (8\%), muurolo-410(14)-dien1-olololoxide (7\%).

Consequently, spraying Achillea millefolium L. plants with potassium nitrate or potassium humate is favored, in order to boost growth, flowering and some chemical constituents. Whereas the application of potassium citrate and potassium silicate induced the highest levels of essential oil content and yield.

\section{REFERENCES}

A.O.A.C. (1990). Official Methods of Analysis of the Association of Official Analytical Chemists, $15^{\text {th }} \quad \mathrm{Ed}$. Washington D.C., USA. 1298 p.

Abd El-Razik, T.M.; Hegazy, Mona H.; Amer, Heba M.; Wahba, Hend E.; Hendawy, S. F. and Hussein, M.S. (2015). Effect of potassium silicate as anti-transpiration on growth, essential oil of chervil plant under Egyptian conditions. International Journal of PharmTech. Research, 8(10): 32-39.

Akinremi, O.O.; Janzen, H.H.; Lemke, R.L. and Larney, F.J. (2000). Response of canola, wheat and green beans to leonardite additions. Canadian J. of Soil Sci., 80: 437-443.

Akram, M.S.; Ashraf, M. and Akram, N.A. (2009). Effectiveness of potassium sulfate in mitigating salt-induced adverse effects on different physio-biochemical attributes in sunflower (Helianthus annuus L.). Flora, 204(6):471-483.

Aydin, S. and Sevindik, E. (2018). Achillea millefolium L. subsp. millefolium essential oil's antifungal effect. Eur J. Biol. Res., 8(3):153-156.

Baggio, C.H.; Freitas, C.S.; Nhaducue, P.F.; Rieck, L. and Marques, M.C.A. (2002). Action of crude aqueous extract of leaves of Achillea millefolium L. (Compositae) on gastrointestinal Tract. Rev. Bras. Farmacogn, 12: 31-33.

Basiouny, N.M.M. (2020). Response of Some Woody Trees to Some Nutrients Under Salinity Stress. M.Sc. Thesis, Fac. Agric., Benha Univ., Egypt, 161 p.

Bednarz, C.W. and Oosterhuis, D.M. (1999). Physiological changes associated with potassium deficiency in cotton. J. Plant Nutr., 22: 303-313.

Bisson, P.; Cretenet, M. and Jallas, E. (1994). Nitrogen, phosphorus and 
potassium availability in the soil physiology of the assimilation and use of these nutrients by the plant, Challenging the Future. Proc. the World Cotton Research Conference, Brisbane Australia, February 14-17, pp. 115-124.

Black, C.A.; Evans, D.O.; Ensminger, LE.; White, J.L.; Clark, F.E. and Dinauer, R.C. (1982). Methods of Soil Analysis. Part 2. Chemical and Microbiological Properties. $2^{\text {nd }}$ Ed. Soil Sci., Soc. of Am. Inc. Publ., Madison, Wisconsin, U. S.A., $1159 \mathrm{p}$.

Bocevska, M. and Sovová, H. (2007). Supercritical $\mathrm{CO}_{2}$ extraction of essential oil from yarrow, Journal of Supercritical Fluids, 40:360-367.

Braga, F.T.; Nunes, C.F.; Favero, A.C.; Pasqual, M.; Carvalho, J.G.D. and Castro, E.M.D. (2009). Caracteristicas anatomicas de mudas de morangueiro micropropagadascom diferentes fonts de silicio. Pesquisa Agropecuaria Brasileira, 44: 128-132.

British Pharmacopeia (1963). Determination of Volatile Oil in Drugs. The Pharmaceutical Press, London, 213 p.

Cakmak, I. (2005). The role of potassium in alleviating detrimental effects of abiotic stresses in plants. J. Plant Nutr. Soil Sci., 168:521-530.

Candan, F.; Unlu, M., Tepe, B.; Daferera, D.; Polissiou, M.; Sokmen, A. and Akpulat, A. (2003). Antioxidant and antimicrobial activity of the essential oil and methanol extracts of Achillea millefolium subsp. millefolium Afan. (Asteraceae). J. Ethnopharmac., 87:215220.

Chalchat, J.C.; Gorunovic, M.S. and Petrovic, S.D. (1999). Aromatic plants of Yugoslavia. I. Chemical composition of oils of Achillea millefolium L. ssp. pannonica (Scheele) Hayak, $A$. crithmifolia W. et K., A. serbica Nym. and A. tanacetifolia All. Journal of Essential Oil Research, 11:306-310.
Chaplin, M.F. and Kennedy, J.F. (1994). Carbohydrate Analysis, 2 ${ }^{\text {nd }}$ ed. Oxford University Press, New York., 344 p.

Duncan, D.B. (1955). Multiple range and multiple F test. Biometrics, 11:1-42.

Düsman, E.; Almeida, I.V.; Coelho, A.C.; Balbi, T.J.; Tonin, L.T.D. and Vicentini, V.E. (2013). Antimutagenic effect of medicinal plants Achillea millefolium and Bauhinia forficata in Vivo. Evid. Based Complement. Alternat. Med. https://doi.org/10.1155/2013/893050

Ebert, G.; Eberle, J.; Ali-Dinar, H. and Lüdders, P. (2002). Ameliorating effects of $\mathrm{Ca}\left(\mathrm{NO}_{3}\right)_{2}$ on growth, mineral uptake and photosynthesis of $\mathrm{NaCl}$-stressed guava seedlings (Psidium guajava L.). Sci Hort., 93:125-135.

Falk, A.J.; Smolenski, S.J.; Bauer, L. and Bell, C.L. (1975). Isolation and identification of three new flavones from Achillea millefolium. J. Pharm. Sci., 64:1838-1842.

Farahani, H.; Sajedi, N.A.; Madani; H; Changizi, M. and Naeini, M. R. (2020). Effect of foliar-applied silicon on flower yield and essential oil composition of Damask rose (Rosa damascena Miller) under water deficit stress. Springer Nature B.V., https://doi.org/10.1007/s12633-02000762-1.

Gao, X.; Zou, C.; Wang, L. and Zhang, F. (2006). Silicon decreases transpiration rate and conductance from stomata of maize plant. J. Plant Nutr., 29:16371647.

Ghatas, Y.A.A. and Mohamed, Y.F.Y. (2020). Influence of some phosphorus sources and biofertilizers (EM and phosphorein) on vegetative growth, fixed oil productivity and chemical constituents of Oenothera biennis L. plant. Scientific J. Flowers and Ornamental Plants, 7(3):247-268.

Goldberg, A.S.; Muller, E.C.; Eigen, E. and Desalva, S.J. (1969). Isolation of the anti- 
inflammatory principles from Achillea millefolium (Compositae). J. Pharm. Sci., 58: 938-941.

Guenther, E. (1961). The Essential Oils, $4^{\text {th }}$ Ed., Vol. I. D. Van Nostrand Comp., New York, pp. 3-13.

Honda, G.; Yesilada, E.; Tabata, M.; Sezik, E.; Fujita, T.; Takeda, Y.; Takaishi, Y. and Tanaka, T. (1996). Traditional medicine in Turkey VI. folk medicine in West Anatolia: Afyon, Kütahya, Denizli, Mugla, Aydin Provinces. J. Ethnopharmacol., 53: 75-87.

Horneck, D.A. and Hanson, D. (1998). Determination of potassium and sodium by flame emission spectrophotometry. In: Kolra, Y.P. (ed.), Hand Book of Reference Methods for Plant Analysis, Taylor and Francis Group, LLC. pp. 153155.

Horneck, D.A. and Miller, R.O. (1998). Determination of Total Nitrogen in Plant Tissue. In: Kolra, Y.P. (ed.), Hand Book of Reference Methods for Plant Analysis, Taylor and Francis Group, LLC. 73 p.

Hornok, L. (1974). The effect of nutrients supply on peppermint yields and essential oil content. Kerteszeti Egyetem Kozlemenyei, 38(6); 73-82.

Hucker, T. and Catroux, G. (1980). Phosphorus in sewage ridge and animal's wastes slurries. Proc. the EEC Seminar, Haren (Gr): Gromingen, 12-13 June, Netherlands.

Jabeen, N. and Ahmed, R. (2011). Foliar application of potassium nitrate affects the growth and nitrate reductase activity in sunflower and safflower leaves under salinity. Not. Bot. Horti. Agrobo., 39(2):172-178.

Jackson, M.L. (1973). Soil Chemical Analysis. Prentice-Hall of Indian Private, New Delhi, India, 478 p.

Jeschke, W.D. and Wolf, O. (1985). Na dependent net $\mathrm{K}$ retranslocation in leaves of Hordeum vulgare cv. 'California
Mariout' and Hordeum distichon cv. 'Villa' under salt stress. J. Plant Physiol., 121:211-223.

Koushyar, H.; Koushyar, M.M.; Byrami, G.; Feizpour, A.; Golamnezhad, Z. and Boskabady, M.H. (2013). The effect of hydroethanol extract of Achillea millefoliumon $\beta$-adrenoceptors of Guinea pig tracheal smooth muscle. Indian J. Pharm. Sci., 75(4):400-405.

Lin, L.T.; Liu, L.T.; Chiang, L.C. and Lin, C.C. (2002). In Vitro anti-hepatoma activity of 15 natural medicines from Canada. Phytother. Res., 16:440-444.

Magen, H. (2004). Potassium in fertigation systems, International Potash Institute (IPI), $5^{\text {th }}$ Fertigation Training Course, Boading, AUH.

Marchand, M. and Bourrié, B. (1999). Use of potash fertilizers through different application methods for high yield and quality crops. Developments in Plant and Soil Sciences, 86(1):13-17.

Marschner, P. (2012). Mineral Nutrition of Higher Plants, $3^{\text {rd }}$ ed. Academic Press, London, UK, 643 p.

Martinez, M.T.; Romers, C. and Gaviler, J.M. (1983). Interactions of foro-acids and humic acids. A Findidad, XI (1): 6162.

Matin, S.R.M.; Mortazavi, S.N. and Heidari, M. (2015). Application of benzyl adenine and potassium nitrate on growth, nitrate content and nitrate reductase activity in narcissus (Narcissus tazetta). International Research Journal of Applied and Basic Sciences, 9 (6):824830.

Mehdi, S.M.; Sarfraz, M. and Hafeez, M. (2007). Response of rice advance line PB-95 to potassium application in saline sodic soil. Pak. J. Biol. Sci., 10:29352939.

Mengel, K. and Kirkby, E.A. (2001). Principles of Plant Nutrition, $5^{\text {th }}$ Ed., 
Kluwer Academic Publishers, Dordrecht, Netherlands 849 p.

Milford, G.F.J. and Johnston, A.E. (2007). Potassium and nitrogen interactions in crop production. Proc. No. 615, International Fertiliser Society, York, UK.

Miri, S.M.; Ahmadi, S. and Moradi, P. (2015). Influence of salicylic acid and citric acid on the growth, biochemical characteristics and essential oil content of thyme (Thymus vulgaris L.). Journal of Medicinal Plants and By-products, 2:141146.

Moghith, W.M.A. (2019). Studies on Growth and Productivity of Chia Plant (Salvia hispanica L.) Under Egyptian Conditions. Ph.D. Thesis, Fac. Agric., Benha Univ, Egypt, 198 p.

Moghith, W.M.A.; Youssef, A.S.M.; Abd El-Wahab, M.A.; Mohamed, Y.F.Y. and Abou El-Ghait, Eman M. (2020). Effect of saline water stress in the presence of silicon foliar application on growth, productivity and chemical constituents of chia (Salvia hispanica L.) under Egyptian conditions. Asian Plant Research Journal, 4(2): 28-45.

Nilforoushzadeh, M.A.; Shirani-Bidabadi, L.; Zolfaghari-Baghbaderani, A.; Saberi, S.; Siadat, A.H. and Mahmoudi, M. (2008). Comparison of Thymus vulgaris (thyme), Achillea millefolium (yarrow) and propolis hydroalcoholic extracts versus systemic glucantime in the treatment of cutaneous leishmaniasis in balb/c mice. J. Vector Borne Dis., 45:301-306.

Oosterhuis, D.M.; Miley, W.N. and Janes, L.D. (1993). A summary of foliar fertilization of cotton with potassium nitrate, Arkansas 1989-1992. Arkansas Fertility Studies. University of Arkansas, Arkansas Agriculture Experiment Station, Bulletin 425: 97-100.

Rahimmalek, M.; Tabatabaei, B.E.S.; Etemadi, N.; Goli, S.A.H.; Arzani, A. and Zeinali, H. (2009). Essential oil variation among and within six Achillea species transferred from different ecological regions in Iran to the field conditions, Industrial Crops and Products, 29: 348-355.

Regina, D. and Katarzyna, W. (2011). The effect of silicon foliar application on the development of seasonal ornamental plants. Acta Agrotanica, 64(4):99-106.

Said-Al Ahl, H.A.H.; Ayad, Hasnaa S. and Hendawy, S.F. (2009). Effect of potassium humate and nitrogen fertilizer on herb and essential oil of oregano under different irrigation intervals, Journal of Applied Sciences, 2(3):319323.

Sampson, B.; Kovar, I.Z.; Rauscher, A.; Fairweather-Tait, S.; Beattie, J.; McArdle, H.J.; Ahmed, R. and Green, C. (1997). A case of hyperzincemia with functional zinc depletion: A new disorder. Pediatr. Res., 42:219-225.

Sangakkara, U.R.; Frehner, M. and Nosberger, J. (2000). Effect of soil moisture and potassium fertilizer on shoot water potential, photosynthesis and partitioning of carbon in mungbean and cowpea. J. Agron. Crop Sci., 185:201207.

Schulz, V.; Hänsel. R. and Tyler, V.E. (2001). Rational Phytotherapy: A Physician's Guide to Herbal Medicine. Springer, Berlin, 294 p.

Snedecor, G.W. and Cochran, W.G. (1989). Statistical Methods, $8^{\text {th }}$ Ed. Iowa State University Press, Ames, 503 p.

Sweetman, S.C. (2002). Martindale: The Complete Drug Reference. $33^{\text {rd }}$ Ed. Pharmaceutical Press, London, 1572 p.

Tozyo, T.; Yoshimura, Y.; Sakurai, K.; Uchida, N.; Takeda, Y.; Nakai, H. and Ishii, H. (1994). Novel antitumor sesquiterpenes in Achillea millefolium. Chemical \& Pharm. Bull., 42: 10961100 . 
Tuberoso, C.I.G. and Kowalczyk, A. (2009). Chemical composition of the essential oils of Achillea millefolium L. isolated by different distillation methods, Journal of Essential Oil Research, 21: 108-111.

Turkmenoglu, F.P.; Agar, O.T.; Akaydin, G.; Hayran, M., and Demirci, B. (2015). Characterization of volatile compounds of eleven achillea species from Turkey and biological activities of essential oil and methanol extract of $A$. hamzaoglui Arabac1 \& Budak. Molecules 20:1143211458.

Van Der Kooi, C.J.; Pen, I.; Staal, M.; Stavenga, D.G. and Elzenga, J.T.M.
(2015). Competition for pollinators and intra-communal spectral dissimilarity of flowers. Plant Biology, 18(1):56-62.

Yaseen, M.; Ahmad, M.; Wani, T.A.; Ahmad, M.; Gani, B.A. and Qureshi, R. (2017). Phytochemical screening and antioxidant activity of extracts of the leaf and stem of Achillea millefolium. Int. J. Sci. Res., 2(6):55-59.

Zekri, M. and Obreza, T.A. (2009). Plant nutrients for citrus trees. UF\IFAS Extension Service, Institute of Food and Agricultural Sciences, University of Florida, USA, 5 p.

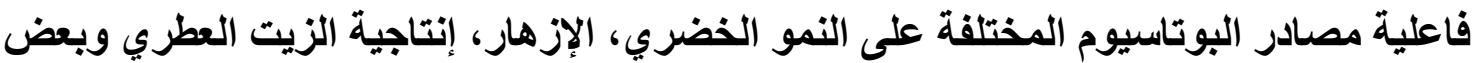

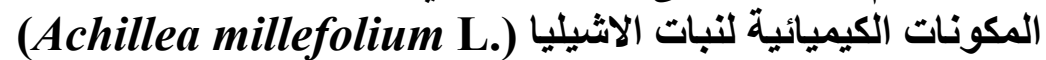

$$
\begin{aligned}
& \text { يسرى فهمى يوسف محمد و ياسر عبد الفتاح عبد العاطي غطاس } \\
& \text { قسم البساتين، كلية الزر اعة، جامعة بنها، مصر عيد العاطي }
\end{aligned}
$$

يعتبر نبات الاشيليا أحد النباتات الطبية والعطرية الهامة ويستخدم الزيت الطيار كضياد للأكسدة، الميكروبات،

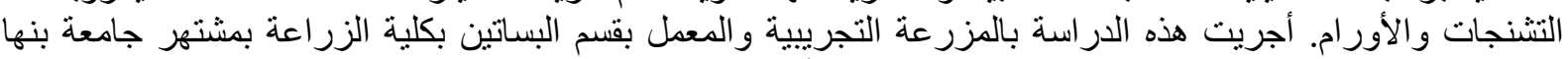

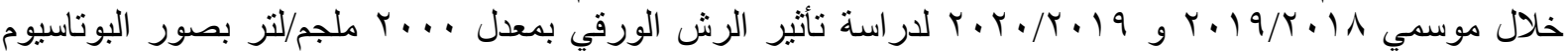

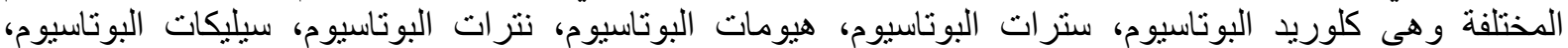

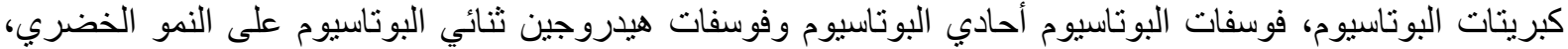

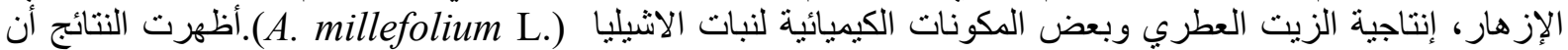

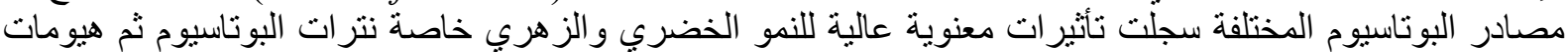

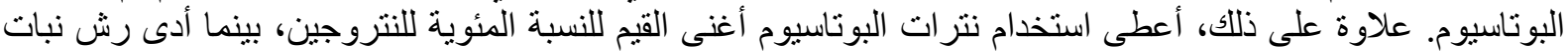

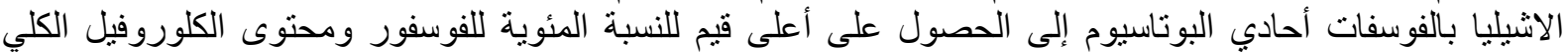

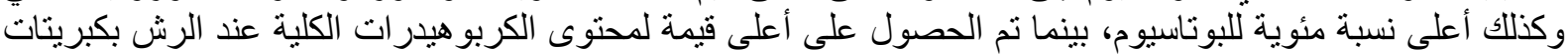

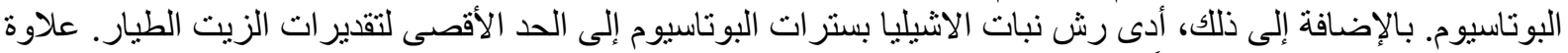

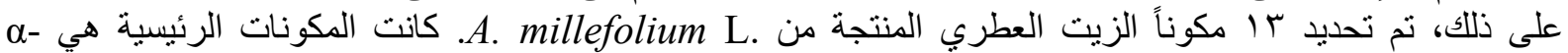
و camazulene ، carvacrol ، limonene ،bisabolol oxide B

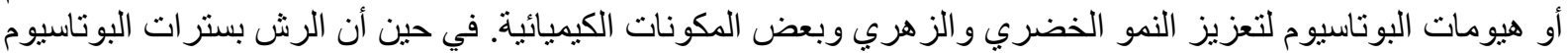

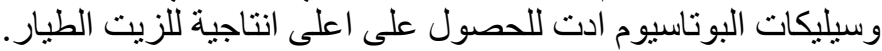

